\title{
Impact of Invasive Plants in Changing Pattern of Native Biodiversity from Vidarbha Region of Maharashtra State
}

\author{
S.P. Rothe ${ }^{1}$, D.A.Dhale ${ }^{2 *}$ \\ ${ }^{1}$ Department of Botany,ShriShivaji College of Arts, Commerce and Science, Akola. \\ ${ }^{1}$ PG-Department of Botany, SSVPS's, L.K.Dr.P.R.Ghogrey Science College, Dhulem, (Maharashtra) \\ India
}

\begin{abstract}
During extensive and intensive exploration of naturalized aliens or exotics from Vidarbha region of Maharashtra state, in last ten years 2003 - 2014, in all 233 plant species were collected from various localities of Vidarbha. These species are naturalized in forest vegetation, along road sides, on margin of ponds, rivers, dams constructed by government. Simultaneously every year, effect of these plants on natural vegetation was studied with continuous observation. Some are maintaining phyto-sociological relationship at the same time, most of the naturalized aliens are producing large number of communities and replacing native species, also they are harmful to human health and animals, some are allergic causing number of skin diseases, dysentery, diarrhoea, gastro-intestinal tract diseases, blindness, bronchial asthma, cough, etc.
\end{abstract}

Keywords: Biodiversity, Invasive plants, Vidarbha Region

\section{INTRODUCTION}

Vidarbha region is comprised by 11 districts viz., Akola, Amravati, Buldhana, Chandrapur, Bhandara, Gadchiroli, Gondia, Nagpur, Wardha, Washim and Yeotmal. In this region forest is dry deciduous type while in some parts like Chandrapur, Gadchiroli, Amravati and Yeotmal luxuriant growth of vegetation is found namely, moist green and moist dry vegetation. At some parts, rivers are flowing nearly for twelve months. Due to availability of water aquatic vegetation is richly developed, while the ponds and dams constructed by government also show marginal aquatic vegetation.

During exploration of naturalized aliens or exotics in all 233 plants are collected from various localities and are identified by using standard floras like Flora of Maharashtra State Volume I \& II for dicotyledones and Flora of Maharashtra State for Monocotyledons. Simultaneously effect of these plants on natural vegetation was studied with the continuous observation. It was noted that some invasive species can change ecosystem processes, such as hydrology and soil chemistry. Most common hydrophytes found in this region are Ammania baccifera, Eichhornia crassipes, Limnophila spp., Lindenbergia spp., Monocharia vaginalis, Potamogeton natans, Typha angustifolia, Pistia strattiodes, Vallisneria spiralis, Gnaphalium leutoalbum whereas on margins of ponds Alternonthera sessilis, Parthenium hysterophorus, Ipomea sinensis, I.carnea, and many species of Cyperaceae and Poaceae. A few of them have flourished crowding out native vegetation. On such area Cyathocline purpurea, Sutera dissecta, Sphaeranthus calva, Leucas biflora, L. cephalotes, Launaea procumbens, Hyptis suaveolens, Ocimum canum, Malvastrum coromandelianum and Sida alba, S. cordifolia, S.ovata, Sonchus aspera, S. oleraceus, S. brachyoptus species are dominant and the wildlife that feeds on it. They are causing harmful effect in the form of diseases. These invasive plants have a competitive advantage because they are no longer controlled by their natural predators and can quickly spread out of control.

Invasion further requires that introduced plant produces reproductive offspring in areas distant from sites of introduction. Taxa that can cope with the abiotic environment and biota in general may invade disturbed semi-natural communities. Invasion of successionally mature undisturbed communities usually requires that the alien taxa overcome a different category of barriers. Invasive alien species are plants, animals; pathogen and other organism that are non-native to an ecosystem and which may cause economic or environmental harm or adversely affect human health viz. pollen grains of Prosopis juliflora, Leucaena glauca, Albizia species, most of the ornamentals planted in garden 
Impatiens balsamina, Zinnia are harmful to human health, due to careless attention now they are naturalized in forest areas, while plants like Parthenium hysterophorus, Lantana camara, Hyptis suaveolens, Alternonthera sessilis, Cassia absus, Cassia uniflora, Ipomoea aquatica, Ipomea carnea causes number of changes in biodiversity. A large number of invasive plants impact adversely upon Biodiversity including decline and elimination of native species, through competition, predation or transmission of pathogens and the distribution of local ecosystems and its functions.

Invasive alien's species introduced and /or spread outside their natural habitats have affected natural biodiversity in almost every ecosystem type on earth and are one of the greatest threats to biodiversity. Since the $17^{\text {th }}$ century, invasive alien species have contributed to nearly $40 \%$ mixed with indigenous flora. The problem continues to grow at great socio-economic health and ecological cost around the world. Invasive alien species exacerbate poverty and threaten development through their impact on Agriculture, forestry, fisheries and natural system, which are the important basis of people's livelihood in the developing countries. This damage is aggravated by climate change, pollution, habitat loss and human induced disturbances. The plants like Parthenium hysterophorus recorded in 1974 from Delhi, it spread throughout India and became dominant in all regions with the replacement of native herbal species from vegetation.

\section{MATERIAL AND MethodS}

An extensive exploration was made throughout the West Vidarbha region. Number of plants observed first and then selected plants are collected from forest which actually plays the role of invasive or they are destroying natural vegetation with the formation of huge population or they may consider as trouble some plants for the creation of vegetation. The collected material was dried and herbarium specimens were prepared and deposited in Department of Botany, ShriShivaji College, Akola. All these collected plant specimens were studied, described in details, in field diary, identified \& classified by using standard floras [1-10]. These are also treated with mercuric chloride for better preservation. We have also recorded some of the phyto-sociological relationship of indigenous plants with some exotics that may be from a long period of time.

\section{RESUlts AND DiscuSSION}

In order to communicate the importance of invasive plants it is important to quantify their economic impact. This is difficult; especially for impacts to biodiversity. Some are regularly used in medicine by herbal vendors and villages while few of them are forage fodder plants for cattle. Regarding invasive alien plants it appears that only some localized removals have been completed in few regions. The limited number of eradication carried out in West Vidarbha so far is probably due to limited awareness of the public and the decision makers, the inadequacy of the legal framework and the scarcity of resources. In many cases the eradications determined a significant recovery of native biodiversity. Invasive plants pose a threat to our native environment and are recognized globally as the second greatest threat to biodiversity. In many areas of Vidarbha, uncontrolled spread of noxious weeds has reduced plant diversity, altered plant and animal habitat and reduced the forage available for wildlife and livestock. Specific impacts of invasive plants infestations include disruption of natural ecosystem processes, alternation of soil chemistry, preventing the regrowth of native plants and economic crops, increased soil erosion, interference with forest regeneration, allergic reactions, severe skin abrasions and burns on people, e.g. Giant hogweed can cause burns and temporary or permanent blindness, use extreme cautious around this plants.

In many areas like forest of chandrapur, Bhandara, Akola, Buldhana, Yeotmal, Melghat of Amravati district and at certain remote areas increased risk of wild fires, livestock and wildlife poisoning. An invasive plant has the ability to thrive and spread aggressively outside its natural range, a naturally aggressive plant may be especially, invasive when it is introduced to a new habitat. Palatable ground and most of the barren land is fully occupied by the Cenchrus, Melanocenchris, Saccharum spontaneous, Rottboelliaco chinchinensis, Setaria verticilata, Aristida redacta, Lophopogon, Heteropogon contortus, Ocimum americanum, Chrysopogon fulvus, while the hedges of the field shows luxuriant growth of Themeda quadrivalavis, Ishaemum rugosum, Perotis, Triumfetta rotundifolia, T. pentandra, Trichodesma zelanica, Ipomoea fistula, Lantana camera, Hyptis suaveolens, Anisomeles indica and the rabi crop fields are dominant with the common weeds like Chrozophorar ottlerianus, Euphorbia rothiana, Chrozophor aprostrata, Convolvulus arvensis, Ipomoea sinensis, Merremia emarginata, Cocculus hirsutus, Striga densiflora and on dried land as well as on rocky situations plants like Lepidogathis subarmata, Apluda mutica, Anisochillus 
Carnosus, Aristida funiculata, Balanites aegyptica, Croton bonplandianum, Corchurus fascicularis, C. trilocularis, Malvastrum coromandelianum, Sida acuta, S. cordifolia are commonly reported. Along margins of ponds: Asteraceae - Ageratum conyzoides, Sophubia delphinifolia, Hygrophila schuli, Lagascea mollis, Bidens biterna, Grangea madraspatna, Cyathocline purpurea, Erigeron asteroides, Blainvillea acmella, Acanthospermum hispidium, Caesulia axillaris, Echinopus echinatus, Sonchus asper, Launaea procumbens, Lagascea mollis, Cichorium intybus. Jaquemontia, Bidens biternata, Xanthium strumaticum, Sigesbeckia, Blumealacera,

Cyperaceae - Cyperus alopecuroides, C. clarkei, C. corymbosus, C. alulatus, C. difformis, C. eleusinoides, C. iria, C. pumilus, C. kyllinga, C. laevugatus, Fuirena wallichiana, Fimbristylis dichotoma, F. miliacea, F. falcata, Scirpus srticulatus, S. ciliaris, S. corymbosus.

Poaceae - Imperata cylindrica, Saccharum officinarum, S. spontaneum, Rottboeliaco chinchinensis, Dicanthium aristatum, Eulaliatri spicata, Ischaemum rugosum, I. laxum, Digitaria ciliaris, Echinochloa colonum, Panicum paspaloides, Cenchrus ciliaris, Chionachne koenigii, Arundo donax, Phalaris hispida, Sporobolus diander, S. indicus, S. capillaris, Dactyloctenium aegyptium, D. indicum, Eragrostiella brachyphylla, Melanocenchrus jacquemontii, Eragrostis gangetica, E. namaquensis, E. tenella, Monochoria vaginalis.

Above listed plants are occurring in a region they are either invasive or troublesome for the natural vegetation.

Table1. Number of plant species in particular Family

\begin{tabular}{|c|l|c|}
\hline Sr. No. & \multicolumn{1}{|c|}{ Name of Family } & Number of Plant Species \\
\hline 1. & Asteraceae & 23 \\
\hline 2. & Cyperaceae & 17 \\
\hline 3. & Poaceae & 45 \\
\hline 4. & Convolvulaceae & 5 \\
\hline 5. & Euphorbiaceae & 5 \\
\hline 6. & Tiliaceae & 2 \\
\hline 7. & Lamiaceae & 4 \\
\hline 8. & Verbenaceae & 1 \\
\hline 9. & Pontederiaceae & 2 \\
\hline
\end{tabular}

\section{REFERENCES}

[1] Cooke, T., The Flora of the Presidency of Bombay London. 2 vols: Repr. Edition, 1958, B. S. I. Calcutta (1901-1908).

[2] Dhore M. A., "Flora of Amravati District with reference to the distribution of tree species".Amravati University, Amravati (2002).

[3] Hooker J. D. , The Flora of British India. London. 7-Vols. 1904.(Rrpr. ed. 1954- 1961. Kent.)

[4] Hooker, J. D. \& T. Thomson, Flora India. London Vol. 1(1955).

[5] Naik, V. N. 1998. Flora of Marathwada Vol. I \&II AmrutPrakashan, Aurangabad (1998).

[6] Sharma B. D., S. Karthikeyen and Singh N.P., Flora of Maharashtra state for Monocotyledon, B.S.I,Western circle, Pune (1996).

[7] Singhs, N. P. and Lakshminarsimhan, P. and S. Prasanna, Karthikeyan S., Flora of Maharashtra State. Dicotyledons. Vol. 2, BSI, Western Circle, Pune(200).

[8] Singh, N. P., Lakshminarsimhan, P., Karthikeyan S. and S. Prasanna, Flora of Maharashtra State. Dicotyledons Vol. 1 BSI, Western Circle, Pune(2001).

[9] Ugemuge N.R., Flora of Nagpur district.AshirvadPrakashan Nagpur (1979).

[10] Yadav S. R. and Sardesai M. M., Flora of Kolhapur District. ShivajiUnivresity, Kolhapur (2002). 